\author{
Joanna Krupska ${ }^{\text {a) }}$, Joanna Hartenberger-Liszek ${ }^{\text {b) }}$ \\ a) Chair of Economics and Management of Transportation Companies, Faculty of Economics, \\ University of Gdansk, Poland \\ b) Chair of Economics and Management of Transportation Companies, Faculty of Economics, \\ University of Gdansk, Poland
}

\title{
TRANSPORT ON OWN ACCOUNT - ESSENCE AND REGULATIONS
}

\begin{abstract}
The article's purpose is to present the idea of transport on own account (non-commercial), its main areas and to assess the role of this type of transport in the creation of road transportation in Poland as well as the identification of regulations and norms which are connected with the possibility to carry out this type of transportation. The article has a character of a review, therefore literature analysis is the main research method used. Statistical data and legal regulations are also analysed. The method of time comparison is used in the article.
\end{abstract}

Keywords: transport on own account, regulations

\section{Introduction}

Transport activity affects other sectors of the economy in a great way, as nearly every business activity is connected with the necessity to use transport services, either in supply, production or distribution. Companies have to choose a model of transport handling, appropriate for the specifics of their activity. Companies can outsource the transport services, to specialised transport entities, thus getting rid of all the connected activities or they can carry out the transport entirely or partially on their own. This is connected with the need to analyse all the legal and organisational regulations in the area of transport on own account. 


\section{The essence of transport on own account}

Transport ${ }^{1}$ is the activity based on the purposeful transportation of cargo or people (Marszałek, 2001, p. 7) with the use of appropriate resources, namely vehicles, which cover the distance between the sender and the recipient of the transport operation (Piskozub, 1975, p. 18). Transport also includes auxiliary services directly or indirectly connected with the transportation, i.e. loading, unloading, preparing the vehicle, stroing, organising the transportation and marketing activities of service provision (Koźlak, 2008, p. 12).

Transport plays a crucial role in the social and economic life of a country, by enabling an effective functioning of every sector of the economy. The transport activity always accompanies other fields of activity, as they need the transportation of a certain amount of cargo and passengers on various distances. Along with the development of the transport, comes the development of other sectors, therefore transport is said to intensify their development (Button, Hensher, Eds., 2001, pp. 255-256). A lack of coherence between transport and other sectors of the economy weakens their growth potential.

There are various classifications and typologies of transport. The division of transport based on the objective of activity is one of them (Tomanek, 2004, p. 16):

- Commercial transport;

- Non-commercial transport (on own account).

Commercial transport is based on the payable transportation of passengers and cargo, therefore its main goal is to be profitable. Meeting this goal determines whether the businessman will choose to carry out transport services. It includes services provided by entities, in which transport is the main activity (road transport companies) and since 2004 also cargo transportation services provided commercially by entities which mainly focus on activity other than transportation, e.g. construction, manufacturing, trade (Szymonik, 2013, p. 96; GUS, 2017). On the other hand, non-commercial transport is centered around the idea of unpaid transportation of goods and passengers, done by the company on his own account, with vehicles which belong to him, as a form of auxiliary activity towards his main activity (this includes transporting employees by the employer with his own buses, in an unpaid manner) (Marszałek, 2001, p. 19). The statistical dictionary of OECD defines transport on own account as "Transport which is not for hire or reward" 2 . Non-commercial transport is described by some authors as transport on own account, whereas the commercial transport can be public or belonging to a sector (Grzywacz, Burnewicz, 1989, p. 51). In literature and public statistics ${ }^{3}$, there is also a term economic transport, i.e. non-commercial, unpaid transport (included in the company's cost), regardless of the type of economic activity (Szymonik, 2013, p. 96; Bentkowska-Senator, Kordel, 2007, p. 31).

\footnotetext{
1 "Transport includes all the activities necessary to move cargo and people, which are technically, organisationally and economically distinguished from other activities" (Madeyski, Lisowska, Marzec, 1971, p. 10).

2 https://stats.oecd.org/glossary/.

3 stat.gov.pl.
} 
The Law on Road Transport (from 06.09.2001) defines non-commercial road transport as a transport on own account (unpaid) of people or cargo carried out by an entrepreneur auxiliarily in his main activity.

Transport on own account can also be provided in a paid way, based on the internal costs. Such an activity is provided as secondary activity, with unused cargo potential, for other companies, institutions or individuals. "Transport on own account mostly carries out transportation work for the needs of the economic entity itself, however, in the reality of market economy, it can also carry out external services in a competitive way" (Wojewódzka-Król, Załoga, Eds., 2016, p. 79). The transportation service might have a commercial character, i.e. priced based on internal costs and a margin, after an appropriate concession (Grzywacz, Burnewicz, 1989, p. 51) (licence) ${ }^{4}$ has been received by the company.

Transport on own account is usually concentrated on transportation which is (Marszałek, 1981, p. 23, 2001; Grzywacz, Burnewicz, 1989, p. 51):

- economic - focused on supplying the company with resources and materials not directly connected with the main activity;

- technological and internal - focused on carrying out the transportation necessary in various phases of the production process;

- supplying - focused on the supply of the company with basic materials used in the production process;

- distributional - performed to deliver sold goods to the customers;

- interventional - used when own fleet is used because the contractor cannot provide the transport service on time;

- auxiliary - including haulage and loading, connected with cargo preparation for commercial transport;

- focused on transporting employees to and from work;

- focused on transporting own resources;

- focused on transporting garbage out of the enterprise.

The extent of transport on own account as an auxiliary activity results from the sector specifics and thus the needs of a given economic entity.

The use of transport on own account in a company may be a result of (Beier, Rutkowski, 1995, p. 67; Abt, 1998, p. 160):

- a comparatory cost analysis which leads to a decision to use own transport;

- a need for a special type of transportation, which is not offered by external contractors;

- a necessity to meet other specific criteria regarding the transport services (e.g. transport elasticity, punctuality control, quality control);

- the will to entirely control the vehicles, the drivers and their activities;

- a need to advertise the company through trademarks shown on the vehicles;

- a need to carry out additional activities by the driver, e.g. selling the goods;

- the strategy of the company and the way the company is envisaged to function on the market.

4 A licence for road transport - An administrative decision provided by a minister appropriate for the transport field or an indicated local government institution, which allows to perform road transport economic activity (Dz. U., 2016). 
Transport on own account can supplement or substitute external contractors (Beier, Rutkowski, 1995, p. 67).

\section{Non-commercial transport - legal regulations}

In case of a situation in which the transport on own account is carried out with the use of vehicles suitable to transport more than 9 people (including the driver) or with a tonnage of above 3.5 tonnes, such transport is regulated by the Law on Road Transport. If a company intends to provide transport with a vehicle with a tractor, so they are a one unit, it should receive a certificate allowing the transport on own account with a tonnage of over 3.5 tonnes.

The specific scope and conditions of performing road transport on own account is described in the Law on Road Transport. It indicates the rules on performing non-commercial road transport dividing it into national and international transport. The transport which is performed on own account in the Republic of Poland is considered to be national non-commercial road transport, whereas the international non-commercial transport is the transport on own account beyond the borders of the Republic of Poland (Dz. U., 2016). Transport on own account (non-commercial) is every ride of a vehicle on public roads, with or without passengers and cargo, carried out by the entrepreneur auxiliarily to his main activity which meets the following criteria ${ }^{5}$ :

- the cargo which is transported belong to the entrepreneur or have been sold, bought, leased, produced, manufactured, mined or repaired by him;

- the goal is to transport cargo or passengers to or from the enterprise or to move them, inside or outside the company on own account;

- the vehicles used for the transportation are driven by the entrepreneur or his employees (i.e. drivers hired based on work contract and not civil contract) ${ }^{6}$;

- the vehicles can be legally used by the entrepreneur (they are purchased, rented or leased);

- the transportation is not a part of provision of tourist services.

If, during the road check the transportation is proven not to meet all of the above criteria, it is treated as road transport.

An economic entity which wants to carry out road transportation as a part of auxiliary activity is obliged to submit an application to receive a certificate for road transportation of goods or passengers nationally ${ }^{7}$ or internationally. The frequency of the transportation doesn't matter. Even if they are incidental and rare, a certificate has to be granted. Entrepreneurs who carry out transportation as a part

5 https://www.biznes.gov.pl/pl/firma/zakladanie-firmy/chce-zalozyc-firme-transportowa/proc_163 7-przewoz-na-potrzeby-wlasne (Dz. U., 2016).

6 According to the Labour Code, a person cannot employee his spouse, therefore it is the only situation in which a driver who is not the enterpreneur, doesn't have a work contract http://www.gitd.pl/ transport-wlasny.

7 These rules do not apply to transport on own account in agriculture, including breeding, husbandry, forestry, gardening, horticulture or fisheries. 
of humanitarian or medical need or in the times of natural catastrophes are exempt from this necessity.

An enterprise which has a certificate which allows it to carry out national transport on own account is obliged to have an extract of the certificate for every vehicle used to carry out the transport. The extract should be stored in the vehicle during the time of the whole transport so as to be presented by the driver during a road check.

A certificate for a national transport on own account is given by the head of a county administration (starosta), where the company is located. A certificate for international transport on own account is given by Chief Road Transport Officer for at most five years. It allows both national and international transport on own account. There is a separate certificate for the international transport on own account for the goods and for the passengers ${ }^{8}$.

\section{Analysis of the volume and type of transport}

In order to assess the scale, dynamics and structure of transport on own account (non-commercial) in Poland, years 2006-2016 were analysed. The total volume of road cargo transport in 2016 was 1546572 thousand tonnes, i.e. 2.7\% more than the year before. $954 \mathrm{mln}$ tonnes were carried out in commercial transport, whereas $592 \mathrm{mln}$ tonnes (i.e. 3.5\% less than the year before) were carried out in economic transport (Table 1). Organisations specialising in transport own $83 \%$ of the fleet, whereas non-transport companies which perform transport on own account own 17\% of the fleet (Wojewódzka-Król, Załoga, Eds., 2016, p. 79).

Table 1. Road cargo transport, thousand tonnes

\begin{tabular}{|c|c|c|c|c|c|c|c|c|c|c|c|}
\hline $\begin{array}{c}\text { Road cargo } \\
\text { transport, } \\
\text { thousand } \\
\text { tonnes }\end{array}$ & 2006 & 2007 & 2008 & 2009 & 2010 & 2011 & 2012 & 2013 & 2014 & 2015 & 2016 \\
\hline Total & 1113880 & 1213246 & 1339473 & 1424883 & 1491253 & 1596209 & 1493386 & 1553050 & 1547883 & 1505719 & 1546572 \\
\hline \multicolumn{12}{|l|}{ Including: } \\
\hline $\begin{array}{l}\text { Commercial } \\
\text { road transport }\end{array}$ & 573392 & 646212 & 691256 & 749559 & 770126 & 839193 & 808297 & 857959 & 874260 & 891978 & 954459 \\
\hline $\begin{array}{l}\text { Economic } \\
\text { road transport }\end{array}$ & 540488 & 567034 & 648217 & 675324 & 721127 & 757016 & 685089 & 695091 & 673623 & 613741 & 592113 \\
\hline
\end{tabular}

Source: (GUS, 2017)

Road cargo transportation in 2016 increased by $38.85 \%$ in comparison to 2006 (base year). Commercial transport increased by $66.5 \%$ in comparison to 2006 (which was the highest increase in the 10 years analysis period), while economic transport only increased by $9.5 \%$. In comparison to the base year 2006, during the 10 year period, there is an increase in dynamics of both the economic and commercial

8 https://www.biznes.gov.pl/pl/firma/zakladanie-firmy/chce-zalozyc-firme-transportowa/proc_163 7-przewoz-na-potrzeby-wlasne; https://www.rp.pl/artykul/1100992-Przewoz-na-potrzeby-wlasnejakich-formalnosci-trzeba-dopelnic.html. 
transport. The highest increase of non-commercial cargo transportation in comparison to the base year was observed in 2011, i.e. an increase by $40 \%$.

Table 2. Dynamics (fixed base and chain) and structure indicators - years 2006-2016 - economic transport

\begin{tabular}{|c|c|c|c|c|c|c|c|c|c|c|c|}
\hline \multicolumn{12}{|c|}{ Dynamics indicators (base - previous year) } \\
\hline $\begin{array}{l}\text { Road cargo transport, } \\
\text { thousand tonnes }\end{array}$ & 2006 & 2007 & 2008 & 2009 & 2010 & 2011 & 2012 & 2013 & 2014 & 2015 & 2016 \\
\hline Total & 103,16 & 108,92 & 110,40 & 106,38 & 104,66 & 107,04 & 93,56 & 104,00 & 99,67 & 97,28 & 102,71 \\
\hline $\begin{array}{l}\text { Commercial road } \\
\text { transport }\end{array}$ & 101,74 & 112,70 & 106,97 & 108,43 & 102,74 & 108,97 & 96,32 & 106,14 & 101,90 & 102,30 & 107,00 \\
\hline $\begin{array}{l}\text { Economic road } \\
\text { transport }\end{array}$ & 104,71 & 104,91 & 114,32 & 104,18 & 106,78 & 104,98 & 90,50 & 101,46 & 96,91 & 91,11 & 96,48 \\
\hline \multicolumn{12}{|c|}{ Dynamics indicators (base - year 2006) } \\
\hline $\begin{array}{l}\text { Road cargo transport, } \\
\text { thousand tonnes }\end{array}$ & 2006 & 2007 & 2008 & 2009 & 2010 & 2011 & 2012 & 2013 & 2014 & 2015 & 2016 \\
\hline Total & 100,00 & 108,92 & 120,25 & 127,92 & 133,88 & 143,30 & 134,07 & 139,43 & 138,96 & 135,18 & 138,85 \\
\hline $\begin{array}{l}\text { Commercial road } \\
\text { transport }\end{array}$ & 100,00 & 112,70 & 120,56 & 130,72 & 134,31 & 146,36 & 140,97 & 149,63 & 152,47 & 155,56 & 166,46 \\
\hline $\begin{array}{l}\text { Economic road } \\
\text { transport }\end{array}$ & 100,00 & 104,91 & 119,93 & 124,95 & 133,42 & 140,06 & 126,75 & 128,60 & 124,63 & 113,55 & 109,55 \\
\hline \multicolumn{12}{|c|}{ Structure indicators } \\
\hline $\begin{array}{l}\text { Road cargo transport, } \\
\text { thousand tonnes }\end{array}$ & 2006 & 2007 & 2008 & 2009 & 2010 & 2011 & 2012 & 2013 & 2014 & 2015 & 2016 \\
\hline Total & 100,00 & 100,00 & 100,00 & 100,00 & 100,00 & 100,00 & 100,00 & 100,00 & 100,00 & 100,00 & 100,00 \\
\hline $\begin{array}{l}\text { Commercial road } \\
\text { transport }\end{array}$ & 51,48 & 53,26 & 51,61 & 52,60 & 51,64 & 52,57 & 54,13 & 55,24 & 56,48 & 59,24 & 61,71 \\
\hline $\begin{array}{l}\text { Economic road } \\
\text { transport }\end{array}$ & 48,52 & 46,74 & 48,39 & 47,40 & 48,36 & 47,43 & 45,87 & 44,76 & 43,52 & 40,76 & 38,29 \\
\hline
\end{tabular}

Source: (own elaboration based on: GUS, 2017)

The lowest share of transport on own account (economic) in the total volume of transportation occured in 2016 (38.29\%) and the highest in 2006, when it amounted to nearly half of all road transportation. Based on a chain analysis, one can observe a decreasing dynamics of transport on own account in the years 2014-2016. In 2014 there was a decrease of $3.09 \%$, in 2015 of nearly $9 \%$ and in $2016-3.5 \%$. The highest increase $(14.3 \%$ ) happened in 2008. Its value was 648217 thousand tonnes.

Non-commercial transport is used mostly for metal ores and other mining and quarrying products (24.7\% of all economic transportation in 2016; 30.2\% in 2015) and other non-metallic mineral products (12.4\% in 2016, $15.2 \%$ in 2015). Food products, beverages and tobacco have a significant share of economic transport (10.7\% in 2016, 9.6\% in 2015). Transport of products of agriculture, hunting, and forestry; fish and other fishing products amounts to $7.7 \%$, other to $7.1 \%$, while the transport of wood and products of wood and cork (except furniture); articles of straw and plaiting materials; pulp, paper and paper products; printed matter and recorded media to $6.3 \%$ in 2016 . Chemicals and chemical products amount to $5 \%$ of total transport on own account, basic metals; fabricated metal products, except machinery and equipment to $5.3 \%{ }^{9}$. Own transport of coke and refined petroleum products have a $3 \%$ share, coal and lignite; crude petroleum and natural

9 Data on 2016. 
gas a share of $2.5 \%$. Transport equipment has an insignificant share of $2.4 \%$, furniture and other manufactured goods a share of $1.7 \%$, machinery and equipment a share of $1.6 \%$ and empty containers a share of $1.6 \%$. The transport of textiles and textile products has the lowest share of $0.3 \%$ (GUS, 2017) (Figure 1).

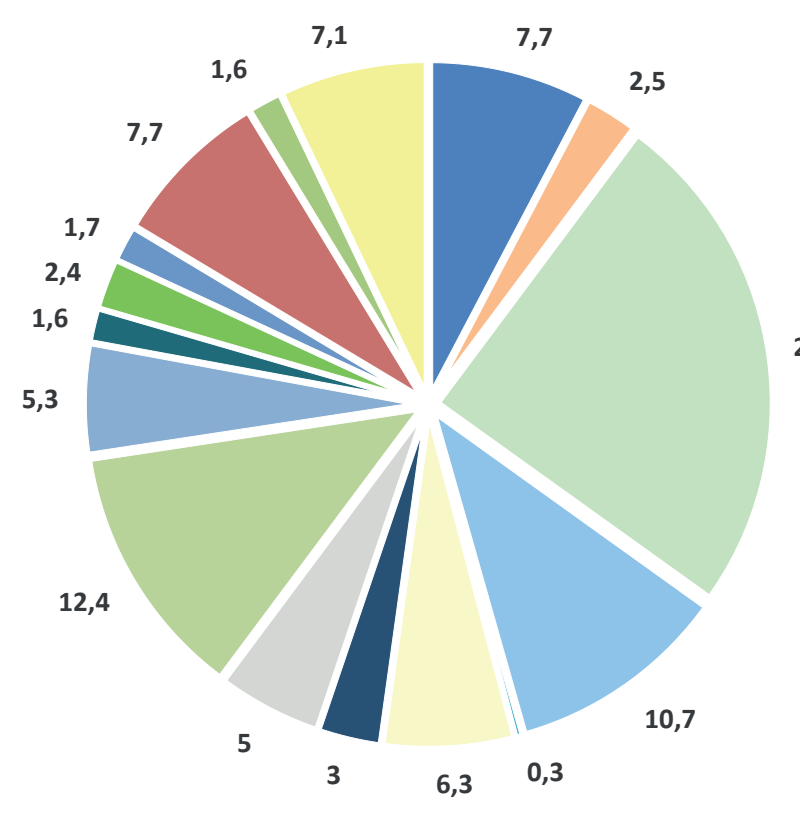

- 1. Products of agriculture, hunting, and forestry; fish and other fishing products

- 2. Coal and lignite; crude petroleum and natural gas

3. Metal ores and other mining and quarrying products

$=4$. Food products, beverages and tobacco

- 5. Textiles and textile products; leather and leather products

6. Wood and products of wood and cork (except furniture); articles of straw and plaiting materials; pulp, paper and paper products; printed matter and recorded media

- 7. Coke and refined petroleum products

$\approx$ 8. Chemicals, chemical products, and man-made fibres; rubber and plastic products

$=$ 9. Other non-metallic mineral products

- 10. Basic metals; fabricated metal products, except machinery and equipment

- 11. Machinery and equipment n.e.c.; office machinery and computers; electrical machinery and apparatus n.e.c.; radio, television and communication equipment and apparatus; medical, precision and optical instruments; watches and clocks

- 12. Transport equipment

-13. Furniture; other manufactured goods n.e.c.

- 14. Secondary raw materials; municipal wastes and other wastes

-15. Empty containers

16. Other goods n.e.c.

Figure 2. Structure of transportation - transport on own account

Source: (own elaboration based on: GUS, 2017) 
The volume of transport on own account and its share in total transportation displays a decreasing tendency but is still a very significant part of all the road cargo transport.

\section{Conclusions}

The transport handling is, beyond doubt, one of the factors affecting the competitiveness of a company. The companies have to choose a transport model, which is effective for them while being in compliance with the demands resulting from the sector specifics and the expectations of the enterprise itself.

A choice of transport on own account as the dominant model of transport handling should be preceded by an analysis of all the important aspects: financial (high financial effort, high fixed costs of maintenance and use), organisational (appropriate organisational structure, technical background, qualified employees, fleet management) and legal.

The volume of cargo transported on own account decreases every year but sill amounts to about $40 \%$ of total cargo. Non-commercial transport is mostly used to transport metal ores and other mining and quarrying products as well as other non-metallic mineral products.

Transport on own account allows the company to adapt the transport handling to individual needs resulting from the sector specifics, the need for quality control, speed and punctuality of the supplies and the ability to provide high elasticity and thus an increase competitive position of the company

\section{References}

Abt, S. (1998), Zarządzanie logistyczne w przedsiębiorstwie, PWE, Warszawa.

Beier, F.J. and Rutkowski, K. (1995), Logistyka, SGH, Warszawa 1995.

Bentkowska-Senator, K. and Kordel, Z. (2007), Polski transport samochodowy ładunków, Kodeks Bydgoszcz, Warszawa.

Button, K.J. and Hensher, D.A. (Eds.). (2001), Handbook of transport systems and traffic control, Pergamon, Amsterdam.

Grzywacz, W. and Burnewicz, J. (1989), Ekonomika transportu, WKŁ, Warszawa.

GUS (2017), Transport - wyniki działalności w 2016, Warszawa.

https://stats.oecd.org/glossary/ [Accessed 13 June 2018].

Koźlak, A. (2008), Ekonomika transportu. Teoria i praktyka gospodarcza, Wydawnictwo Uniwersytetu Gdańskiego, Gdańsk.

Madeyski, M., Lisowska, E. and Marzec, J. (1971), Wstęp do nauki o transporcie, SGPiS, Warszawa.

Marszałek, S. (1981), Poradnik transportowca w instytucjach i jednostkach gospodarczych, WKE, Warszawa.

Marszałek, S. (2001), Ekonomika, organizacja i zarządzanie w transporcie, Wyższa Szkoła Zarządzania w Katowicach, Katowice.

Piskozub, A. (1975), Ekonomika transportu - podstawy metodologiczne, WKŁ, Warszawa.

Szymonik, A. (2013), Ekonomika transportu dla potrzeb logistyka(i). Teoria i praktyka, Difin, Warszawa.

Tomanek, R. (2004), Funkcjonowanie transportu, Wydawnictwo Akademii Ekonomicznej im. O. Langego w Katowicach, Katowice. 
Ustawa z dnia 6 września 2001 r. o transporcie drogowym (Dz. U. z 2016 r., poz. 187).

Wojewódzka-Król, K. and Załoga, E. (Eds.). (2016), Transport. Nowe wyzwania, Wydawnictwo Naukowe PWN, Warszawa.

www.biznes.gov.pl [Accessed 13 June 2018].

www.gitd.pl [Accessed 13 June 2018].

www.rp.pl [Accessed 13 June 2018].

\section{Corresponding authors}

Joanna Krupska can be contacted at: j.krupska@ug.edu.pl

Joanna Hartenberger-Liszek can be contacted at: jhart@gnu.univ.gda.pl 